\title{
The Effect of Military Ethics and Motivation on The National Commitment of The Indonesian Military
}

\author{
Bambang Heru Sukmadi \\ State University of Jakarta \\ Email: bambangheru_im16s3@mahasiwa.unj.ac.id \\ Ma'ruf Akbar \\ State University of Jakarta \\ Email: maruf.akbar@unj.ac.id \\ Billy Tunas \\ State University of Jakarta \\ Email: tunas.billy@gmail.com \\ Zulfia Khalid \\ State University of Jakarta \\ Email: khalidzulvia@gmail.com
}

\begin{abstract}
This research is aimed to explore and find out the effect of military ethics and motivation on the national commitment of the soldiers of the Indonesian Army. The research is conducted on the soldiers in the rank of non-commissioned and enlisted soldiers at one of the Indonesian Army units in Jakarta. The data is collected with the survey method on the sample that comprises of 83 respondents which are taken with a simple random sampling technique. The data is analyzed quantitatively from an organizational behavior perspective with the Path Analysis technique. The test of normality and linearity of each regression between variables results in a normal distribution of residual and linearly related. The results of this research show that (1) military ethics has a positively direct effect on national commitment; (2) military ethics has a positively direct effect on motivation; (3) motivation has a positively direct effect on national commitment; (4) military ethics has an indirect effect on national commitment through motivation.
\end{abstract}

Keywords: National commitment, Military ethics, Motivation, Indonesian military

\section{INTRODUCTION}

Since entering the 20th century the process of globalization has been accelerating with increasingly strong influence reaching all corners of the world. The world seems to turn into a global village. The encounters among people from different parts of the world with various lifestyles, cultures, and interests bring impacts into a nation positively as well as negatively. The impacts on the national identity of a nation are inevitable (Bechhofer \& McCrone, 2009; McCrone $\&$ Bechhofer, 2015). The life of a nation faces an increasingly strong attraction between centrifugal forces which bring outward looking insight and centripetal forces that bring inward looking insight (Supriyatno, 2014). The attractions of these two forces have given rise to the global paradox phenomenon. When the world seems to unite, small forces emerge in the field of various aspects of life such as political, economic, social and cultural (Naisbitt, 1994). Globalization brings about the growing of cosmopolitanism and the weakening of nationalism. At 
the same time, the weakened sense of nationality of some citizens brings the tendency of individualism (Soebhan, 2017) and raises the expression of self-identity that is often excessive based on their narrow primordial ties (Waluyo R. Jati, 2017).

Such conditions are consistent with the results of research conducted by Mau et al. in Germany, by Tiley and Heath in England, and Ashuri in the United States of America (Ariely, 2012). Similarly, the results of a study in Israel showed that $54 \%$ of high school students tended to avoid compulsory military service (Adres, Vanhuysse, \& Vashdi, 2012). Whereas in Indonesia, the results of a study stated that $59.9 \%$ of respondents had hatred towards certain groups which 92.2\% disagreed if there were members of the hated group became government officials and $82.4 \%$ did not want to live next door (Azis, 2017). According to the results of research conducted by Sairin, the adoption of global modernity in the midst of some traditional Indonesian society has resulted in cultural ambiguity. The community is no longer traditional but also not modern. As a result, cosmopolitan culture evolved in one group, while sectarianism grew stronger in other groups (Sairin, 2004). For that reason, national commitment is deemed feasible to be studied especially for the soldiers because national commitment is the backbone of the military profession (Gal, 1985). Accordingly, this study aims to find out the effect of military ethics and motivation on the national commitment of soldiers in the Indonesian military. The variable of national commitment is defined as an intersection between the variable of organizational behavior and the variable of personality and cultural values. Those two variables are intersected because national commitment does not comprise the dimension of continuance commitment, while it comprises several dimensions of the variable of personality and cultural values. Several dimensions of personality and cultural values covered in national commitment are conscientiousness, agreeableness, emotional stability, and collectivism. This definition of national commitment is the novelty or the state of the art of the study.

\section{LITERATURE REVIEW}

In this research, the national commitment of soldiers is studied in the perspective of organizational behavior. However, based on 15 organizational behavior variables as theorized by Colquitt, LePine, and Wesson there are no national commitment variables (Colquitt, LePine, \& Wesson, 2015). The variable of organizational behavior that has a closest, although not exactly the same, meaning to national commitment is organizational commitment. Of course, the soldiers are organized into military units (organizations), but the commitment is not limited to the interests of the organization. The commitment extends to beyond the organization interests which is the interests of the nation who had created the military organization. The soldiers even remain committed to national interests when they have retired and no longer to be a member of the military unit. In addition, the realm of national commitment comprises only affective commitment and normative commitment. It is different from organizational commitment which consists of affective, normative, and continuance commitment (Colquitt et al., 2015). In order that the commitment includes national interests, it should be featured with several relevant aspects of personality and cultural values variable. Those aspects are conscientiousness, agreeableness, and emotional stability which are the aspects of personality, and collectivism which is the main aspect of cultural values (Colquitt et al., 2015; Deresky, 2014; Gibson et al., 2012; Langton, Robbins, \& Judge, 2016).

Thus it can be said that the variable of national commitment is the intersection between organizational commitment with personality and cultural values. This construction of national commitment is the result of deductive reasoning from the theory along with inductive reasoning from the results of various empirical studies such as those conducted by Choi, Oh, \& Colbert (2015); Cohen (2011); Syed, Saeed, \& Farrukh (2015); and Williamson, Burnett, \& Bartol (2009). The results of those empirical studies demonstrate that the several aspects of personality and cultural value mentioned have closely related to commitment. 
Regarding military ethics, ethics refers to moral norms that determine whether an action is right or wrong so that the outcome is good or bad (McShane \& Von Glinow, 2018). Ethics provide moral guidance to decide what actions must or must not be done. The decision in question is not only organizational decisions but also one's decisions on his/her own actions. How far the application of ethics in behavior is determined by the level of concern for ethical issues, the degree of consistent intention to apply the ethical norms, and the level of will power to apply the ethical norms into behavior (Colquitt et al., 2015).

There is ethics which only applies to persons with certain professions which are formulated into a professional code of ethics including military ethics. Based on the professional code of ethics, the professionals are not only bound by authoritative legal norms but are also by philosophical moral norms. Therefore, the professional community can also be called a moral community (Bertens, 2013).

Within the Indonesian military including the Army, there are two codes of ethics, namely Sumpah Prajurit (Soldier's Oath) and Sapta Marga (Seven Ways). Those two codes of ethics are moral norms for carrying out the duties of the Indonesian military in serving the state and nation. Soldier's Oath is a vow/promise of every soldier before God Almighty, while Seven Ways is a statement of morality as citizens, patriots, knights, and Indonesian soldiers to serve the country and nation of Indonesia.

Relating to national commitment, various theories explain that ethics has a positive effect on national commitment which includes the aspects of affective commitment, normative commitment, conscientiousness, agreeableness, emotional stability, and collectivism (Colquitt et al., 2015; George \& Jones, 2012; Ivancevich, Konopaske, \& Matteson, 2014; Robbins \& Judge, 2017). Some studies also provide empirical evidence of this effect, for example, research conducted by Moore \& Moore (2014); Novianti \& Gunawan (2010); Okpara \& Wynn (2008); and Vitell \& Singhapakdi (2008).

Colquitt et al. (2015); George \& Jones (2012); and Langton et al. (2016) also explained that aspects of national commitment were also positively influenced by motivation. Motivation is the inner (intrinsic motivation) or outer (extrinsic motivation) driving force of a person that determines the direction, intensity, and persistence of his/her actions to achieve certain goals (Colquitt et al., 2015). If the goal has not been achieved, strong motivation will persist and then become a commitment (Hernandez, 2010). The positive influence of motivation on national commitment is also proven empirically in the results of several studies, for example, those conducted by Asgari (2014); Huang (2015); and Rahmawati, Abiddin, \& Ro'is (2015).

A brief description above has explained that various theories and research shows that ethics has a positive effect on national commitment and motivation, while motivation itself also has a positive effect on national commitment. Based on sillogism logic (Suriasumantri, 2017), it can be concluded that ethics also has an indirect effect on national commitment through motivation. Therefore, this study aims to (1) study and find out the direct effect of military ethics on the national commitment of the Indonesian soldiers; (2) study and find out the direct effect of the military ethics on the motivation of the Indonesian soldiers; (3) study and find out the direct effect of motivation on the national commitment of the Indonesian soldiers; and (4) study and find out the indirect effect of military ethics on the national commitment of the Indonesian soldiers through motivation.

\section{METHODOLOGY}

The effect of military ethics and motivation on national commitment was studied in the perspective of organizational behavior with a quantitative approach. The research was carried out in one of the Indonesian army units in Jakarta. The number of respondents is 83 people that consist of the soldier in the rank of non-commissioned and enlisted. Due to the population is homogeneous, the sample is taken with a simple random technique. Data collection used survey methods through questionnaire items that must be answered by respondents. Then, the collected 
data was quantified on a one to five scales. Product Moment correlation is used to test the validity of the research instrument, while the reliability is measured based on the Alpha Cronbach value. The test applied to 30 respondents result in 100 valid instruments out of 109. The Alpha Cronbach value of national commitment: 0.923; soldier ethics: 0,916; and motivation: 0.946, which means the reliability of the instrument for each variable is high (good).

Those 100 valid instruments were used to measure the variables studied. Each of variables is measured on its indicators. The indicators of national commitment are derived from the definition of organizational commitment as an emotional commitment and the definition of personality and cultural values (Colquitt et al., 2015; George \& Jones, 2012; Mercurio, 2015). Based on the definition, the indicators of national commitment (Y) are (1) suitability of individual values with the profession; (2) caring and pride in the Indonesian military and nation; (3) willingness to work beyond the call of duty; (4) strong desire to succeed in every task; (5) strong desire to build togetherness; and (6) satisfaction in addressing works and life. The indicators of military ethics are based on Four-Component Model of Ethical Decision Making (Colquitt et al., 2015). The indicators of military ethics $\left(\mathrm{X}_{1}\right)$ are (1) the level of concern for ethical issues; (2) the level of consistency of the desire to implement a code of ethics; and (3) the level of will power to apply the code of ethics into behavior. The indicators of motivation are based on McClelland's Needs Theory (Bateman \& Snell, 2015). The indicator of motivation $\left(X_{2}\right)$ are (1) the desire for achievement; (2) the desire for affiliation; and (3) the desire to use social power. The numerical data collected was analyzed quantitatively with the Path Analysis technique utilizing SPSS 22 software.

The indicators of each variable are recapitulated as shown in Tabel-1, and the model of the research is depicted in Figure-1.

Table-1. Operational Table

\begin{tabular}{|c|c|c|c|}
\hline No. & Variable & Indicator & Reference \\
\hline 1 & $\begin{array}{l}\text { National } \\
\text { Commitment }\end{array}$ & $\begin{array}{l}\text { 1. Suitability of individual values } \\
\text { with the profession } \\
\text { 2. Caring and pride in the Indonesian } \\
\text { military and nation } \\
\text { 3. Willingness to work beyond the } \\
\text { call of duty } \\
\text { 4. Strong desire to succeed in every } \\
\text { task } \\
\text { 5. Strong desire to build togetherness } \\
\text { 6. Satisfaction in addressing works } \\
\text { and life }\end{array}$ & $\begin{array}{l}\text { Colquitt, LePine, and } \\
\text { Wesson, 2015; George } \\
\text { and Jones, 2012; } \\
\text { Mercurio, 2015 }\end{array}$ \\
\hline 2 & Military Ethics & $\begin{array}{l}\text { 1. The level of concern for ethical } \\
\text { issues } \\
\text { 2. The level of consistency of the } \\
\text { desire to implement a code of } \\
\text { ethics } \\
\text { 3. The level of will power to apply } \\
\text { the code of ethics into behavior }\end{array}$ & $\begin{array}{l}\text { Colquitt, LePine, and } \\
\text { Wesson, } 2015\end{array}$ \\
\hline 3 & Motivation & $\begin{array}{l}\text { 1. The desire for achievement } \\
\text { 2. The desire for affiliation } \\
\text { 3. The desire to use social power }\end{array}$ & Bateman and Snell, 2015 \\
\hline
\end{tabular}




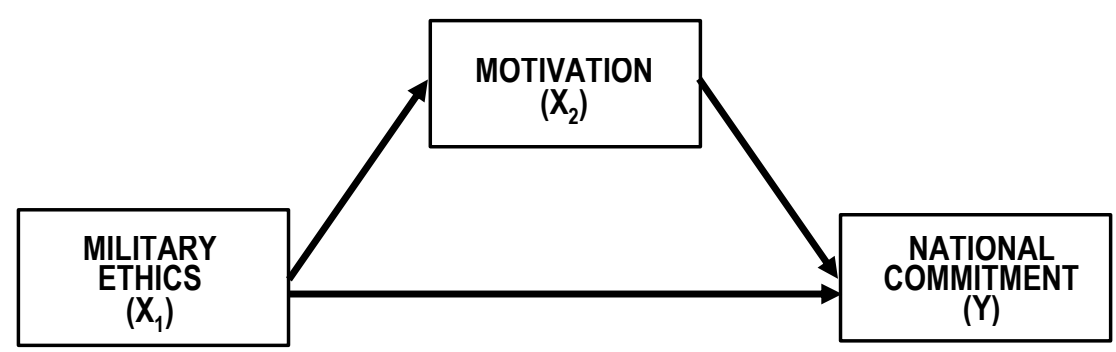

Figure-1. Research Model

According to the model, thera are four research hypotheses to be tested. Those are:

$\mathrm{H}_{1}$ : Military ethics has a positive direct effect on national commitment.

$\mathrm{H}_{2}$ : Military ethics has a positive direct effect on motivation.

$\mathrm{H}_{3}$ : Motivation has a positive direct effect on national commitment.

$\mathrm{H}_{4}$ : Military ethics has an indirect effect on national commitment through motivation.

Prior to data analyzing and hypotheses testing, the test of normality and linearity are applied to the data to meet the analysis requirements unless the result of the analysis will not be valid to predict the population. The normality test is to determine whether the estimated residual in each regression is normally distributed, the linearity test is to determine whether the relationships between variables in each regression are linear. The estimated residuals are normally distributed if the value of asymp. sig. (asymptotic significance) of the regression between two variables is greater than 0.05 , and two variables are linearly related if the value of sig. is smaller than 0.05 . The results of the test of analysis requirements indicate that the estimated residuals in each regression are normally distributed, and each relationship between two variables is linear. A summary of the results of the normality and linearity test is presented in Table-2.

Tabel-2. The Result of Analysis Requirements Test

\begin{tabular}{ccccc}
\hline \multirow{2}{*}{ Regression } & \multicolumn{2}{c}{ Normality } & \multicolumn{2}{c}{ Linearity } \\
\cline { 2 - 5 } & Asymp. Sig. & Conclusion & Sig. & Conclusion \\
\hline $\mathrm{Y}$ on $\mathrm{X}_{1}$ & $0,200>0,05$ & Normal & $0,000<0,05$ & Linear \\
\hline $\mathrm{X}_{2}$ on $\mathrm{X}_{1}$ & $0,065>0,05$ & Normal & $0,000<0,05$ & Linear \\
\hline $\mathrm{Y}$ on $\mathrm{X}_{2}$ & $0,200>0,05$ & Normal & $0,000<0,05$ & Linear \\
\hline
\end{tabular}

\section{RESULT AND DISCUSSION}

\section{Descriptive Statistic}

The statistics of national commitment variable comprises of mean: 121.71 ; mode: 125 , and standard deviation: 7.171. The calculated coefficient of skewness is -0.459 . The sequential list of mean score from the highest to lowest based on the measurement of each indicator is (1) caring and pride in the Indonesian military and nation: 394.75 ; (2) suitability of individual values with the profession; 377.00; (3) strong desire to build togetherness: 374.80; (4) strong desire to succeed in every task; 369.00; (5) satisfaction in addressing works and life: 368,60; and (6) willingness to work beyond the call of duty: 361.25 .

The statistics of military ethics variable comprises of mean: 99.4; mode: 100, and standard deviation: 5.548. The calculated coefficient of skewness is -0.108 . The sequential list of mean score from the highest to lowest based on the measurement of each indicator is (1) the level of concern for ethical issues: 381.11 ; (2) the level of will power to apply the code of ethics into behavior: 372.57 ; (3) the level of consistency of the desire to implement a code of ethics: 368.67. 
The statistics of motivation variable comprises of mean: 118,65; mode: 119 , and standard deviation: 8.005. The calculated coefficient of skewness is -0.044 . The sequential list of mean score from the highest to lowest based on the measurement of each indicator is (1) the desire for achievement: 374.78 ; (2) the desire to use social power: 360.78 ; and (3) the desire for affiliation: 358.67 .

\section{Calculation of Coefficients}

Path analysis was performed on Structure-1 which analyzed the regression of national commitment on ethics and motivation, and Structure-2 which analyzed the regression of motivation on ethics. The results of the analysis on Structure-1 in the form of SPSS output are presented in Table-3 and Table-4.

Table-3. Model Summary of Structure-1

\begin{tabular}{ccccc}
\hline Model & $\mathrm{R}$ & R Square & $\begin{array}{c}\text { Adjusted } \\
\text { R Square }\end{array}$ & $\begin{array}{c}\text { Std. Error of } \\
\text { the Estimate }\end{array}$ \\
\hline 1 & $.664^{\mathrm{a}}$ & .442 & .428 & 5.426 \\
\hline
\end{tabular}

a. Predictors: (Constant), Motivation, Ethics

Table-4. Coefficients of Structure- $1^{\mathrm{a}}$

\begin{tabular}{|c|c|c|c|c|c|c|}
\hline & \multirow[b]{2}{*}{ Model } & \multicolumn{2}{|c|}{$\begin{array}{l}\text { Unstandardized } \\
\text { Coefficients }\end{array}$} & \multirow{2}{*}{$\begin{array}{c}\text { Standardized } \\
\text { Coefficients } \\
\text { Beta }\end{array}$} & \multirow[b]{2}{*}{$\mathrm{t}$} & \multirow[b]{2}{*}{ Sig. } \\
\hline & & B & Std. Error & & & \\
\hline \multirow[t]{3}{*}{1} & (Constant) & 30.693 & 11.627 & & 2.640 & 0.010 \\
\hline & Etika & .490 & .122 & .379 & 4.022 & 0.000 \\
\hline & Motivasi & .357 & .084 & .398 & 4.231 & 0.000 \\
\hline
\end{tabular}

a. Dependent Variable: Commitment

In Table-3 it can be seen that the regression coefficient of national commitment to ethics is 0.379. This means that every addition of 1 unit of ethics will increase national commitment by 0.379 units. The regression coefficient of national commitment to motivation is 0.398 , which means that every addition of 1 unit of motivation will increase national commitment by 0.398 units. In Table-2, it can calculate the effect of other variables outside the Structure-1 model on national commitment, which is equal to: $\sqrt{1-R^{2}}=\sqrt{1-0,442}=0.747$. While the amount of $R$ Square: 0.442 means that the ability of the Structural-1 model to explain the variation in national commitment is $44.2 \%$. Based on these calculations, it can be arranged Structure-1 regression equation that is $\mathrm{Y}=0.379 \mathrm{X}_{1}+0.398 \mathrm{X}_{2}+0.747$.

The results of the analysis on Structure- 2 in the form of SPSS output are presented in Table-5 and Table-6.

Table-5. Model Summary of Strcture-2

\begin{tabular}{ccccc}
\hline Model & $\mathrm{R}$ & $\mathrm{R}$ Square & $\begin{array}{c}\text { Adjusted } \\
\mathrm{R} \text { Square }\end{array}$ & $\begin{array}{c}\text { Std. Error of } \\
\text { the Estimate }\end{array}$ \\
\hline 1 & $.461^{\mathrm{a}}$ & .213 & .203 & 7.146 \\
\hline
\end{tabular}

a. Predictors: (Constant), Ethics 
Table-6. Coefficients of Structure- $2^{\mathrm{a}}$

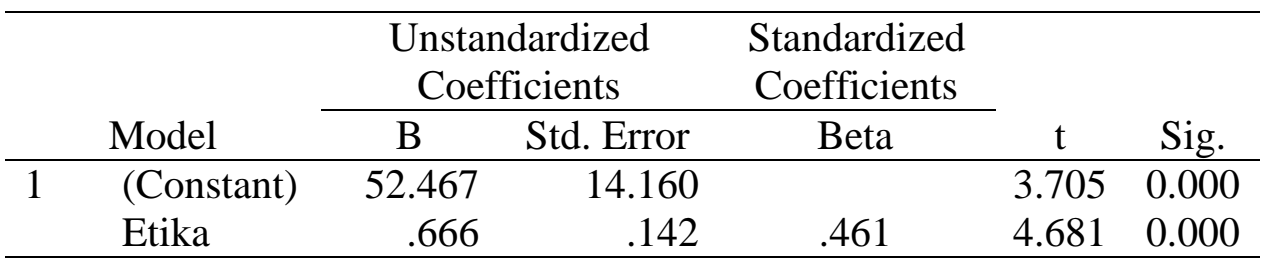

a. Dependent Variable: Motivation

In Table-5 it can be seen that the regression coefficient of motivation to ethics is 0.461 . This means that every addition of 1 unit of ethics will increase motivation by 0.379 units. In Table-4, it can calculate the effect of other variables outside the Structure-2 model on motivation, which is equal to: $\sqrt{1-R^{2}}=\sqrt{1-0,213}=0.887$. While the amount of R Square: 0.213 means that the ability of the Structural-2 model to explain the variation in motivation is $21.3 \%$. Based on these calculations, it can be arranged Structure-2 regression equation that is $\mathrm{X}_{2}=0.461 \mathrm{X}_{1}+$ 0.887 .

Based on the results of statistical calculations above, the indirect effect of ethics on national commitment through motivation $=$ the effect ethics on motivation $\mathrm{x}$ the effect of motivation on national commitment $=0.461 \times 0.398=0.183$. Thus, the total effect of ethics on national commitment, that is direct and indirect effect simultaneously, $=0.379+0.183=0.562$. This magnitude shows that the existence of motivation as a mediator variable has strengthened the effect of ethics on national commitment.

\section{Test of Hypotheses}

\section{a. Hypothesis-1 (H1)}

In Table-3, the regression of national commitment to ethics shows the value of coefficient $=0.379 ;$ sig. $=0,000 ;$ and $t_{\text {count }}=4,022$. The number of respondents is 83 and the number of variables is three, then the value of $t_{\text {table }}=1.664$. Thus $H_{1}$ is accepted, because sig. $=0,000<0.05$ and $t_{\text {count }}>t_{\text {table. }}$. In conclusion, ethics has a positive direct effect on national commitment.

\section{b. Hypothesis-2 $\left(\mathbf{H}_{2}\right)$}

In Table-5, the regression of motivation to ethics shows the value of coefficient $=0.461$; sig. $=0,000$; and $t_{\text {count }}=4,681$. The number of respondents is 83 and the number of variables is three, then the value of $t_{\text {table }}=1.664$. Thus $\mathrm{H}_{2}$ is accepted, because sig. $=0,000<0.05$ and $t_{\text {count }}>$

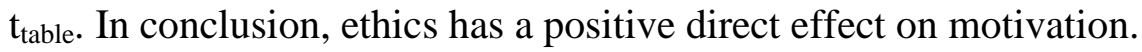

\section{c. Hypothesis-3 $\left(\mathrm{H}_{3}\right)$}

In Table-3, the regression of national commitment to motivation shows the value of coefficient $=0.398 ;$ sig. $=0,000$; and $t_{\text {count }}=4,231$. The number of respondents is 83 and the number of variables is three, then the value of $t_{\text {table }}=1.664$. Thus $\mathrm{H}_{3}$ is accepted, because sig. $=$ $0,000<0.05$ and $t_{\text {count }}>t_{\text {table }}$. In conclusion, motivation has a positive direct effect on national commitment.

\section{d. Hypothesis-4 $\left(\mathrm{H}_{4}\right)$}

The Sobel Test technique is used to test the hypothesis of an indirect effect. The test is based on the value of $\mathrm{z}$. If the value of $\mathrm{z}>1.96$, then the hypothesis is accepted (Hayes, 2018; Preacher \& Hayes, 2004). The formula to calculate the value of $\mathrm{z}$ is (Bimo, 2017; MacKinnon, 2008):

$$
\begin{aligned}
& \mathrm{z}=\frac{\mathrm{ab}}{\sqrt{\left(\mathrm{b}^{2} S \mathrm{Ea}^{2}\right)+\left(\mathrm{a}^{2} \mathrm{SEb}^{2}\right)}} \\
& \text { where: }
\end{aligned}
$$

a: Unstandardized regression coefficient of $X_{2}$ to $X_{1}$.

b: Unstandardized regression coefficient of $\mathrm{Y}$ to $\mathrm{X}_{2}$. 
$\mathrm{SE}_{\mathrm{a}}$ : Standard Error of Estimation of the regression of $\mathrm{X}_{2}$ to $\mathrm{X}_{1}$.

$\mathrm{SE}_{\mathrm{b}}$ : Standard Error of Estimation of the regression of $\mathrm{Y}$ to $\mathrm{X}_{2}$.

Based on Table-3 and Table-5:

$\mathrm{z}=\frac{(0,666)(0,357)}{\sqrt{\left(0,357^{2} 0,142^{2}\right)+\left(0,666^{2} 0,084^{2}\right)}}=3,1493$.

Thus $\mathrm{H}_{4}$ is accepted, because $\mathrm{z}=3.1493>1.96$. In conclusion, ethics has an indirect effect on national commitment through motivation.

The results of this study prove that increasing ethics causes directly an increase in national commitment, an increase of ethics causes directly an increase in motivation, an increase in motivation causes directly increase in national commitment and an increase in ethics causes indirectly an increase in national commitment through motivation. Thus, the results of this study have corroborated the theories and the result of previous relevant researches. In comparison with the previous research, it can be known that in this study some dimensions of organizational commitment and some dimensions of personality and cultural values are integrated to be the dimensions of national commitment variable, while in the previous research the variable of organizational commitment and the variable of personality and cultural values are positioned separately as two different entities of a variable.

Due to the mediation of motivation in the relationship between ethics and national commitment, the effect of ethics on national commitment indirectly through motivation is greater than the direct effect of motivation on national commitment. Accordingly, the effort of the strengthening of national commitment should be prioritized firstly in the improvement of ethics, and the improvement of motivation is put as the second priority. On the other hand, the effort to improve ethics is prioritized firstly in the increase of the consistency of the application of the code of ethics, the second is the intention to apply the code of ethics, and the third is the concern for ethical issues. The effort to improve motivation is prioritized firstly in the increase of the desire for affiliation, the second is the desire to use social power, and the third is the desire for achievement.

The descriptive statistics of ungrouped data of national commitment, ethics, and motivation show that each of them has a negative coefficient of skewness. This negative value indicates the tendency of the score to clustered to the right of the mean. This means that the condition of the national commitment, ethics, and motivation of the soldiers to tend to be good. However, the condition of national commitment still needs to be improved, especially for soldiers whose scores are still below average. In addition, it also has been underlined the great importance of national commitment as the backbone of the military profession.

\section{CONCLUSION}

Based on the research described above, it can be concluded that (1) ethics has a direct effect positively on the national commitment of the soldiers; (2) ethics has a direct effect positively on the motivation of the soldiers; (3) motivation has a direct effect positively on the national commitment of the soldiers; and (4) ethics has an indirect effect on the national commitment of the soldiers through motivation.

The researcher realizes that the condition of the national commitment variable is affected by many variables within and from outside the organization. But due to limited time and resources, the study in this research is limited to the scope of the effect of ethics and motivation. Therefore, further research with more influential variables involved is needed in order to get more comprehensive results. However, the researcher expects the research to be beneficial practically and theoretically. The practical benefit refers to the use of the research by the Indonesian military as an input to the efforts of increasing the national commitment of the soldiers. While the theoretical benefit is that it can enrich the corpus of human resource management science, 
especially in the field of organizational behavior, and more specifically within the scope of military organization.

\section{REFERENCE}

Adres, E., Vanhuysse, P., \& Vashdi, D. R. (2012). The Individual's Level of Globalism and Citizen Commitment to the State: The Tendency to Evade Military Service in Israel. Armed Forces and Society, 38(1).

Ariely, G. (2012). Globalisation and The Decline of National Identity? An Exploration Across Sixty-Three Countries. Journal of the Association for the Study of Ethnicity and Nationalism, 22(1).

Asgari, M. R. (2014). The Effect Leadership Style on Employee Commitment to Services Quality in Bank Melli Branches of Isfahan. Kuwait Chapter of Arabian Journal of Business and Management Review, 3(12).

Azis, M. (2017, January 19). Melawan Narasi Kebencian. Harian Kompas.

Bateman, T. S., \& Snell, S. A. (2015). Management. Leading and Collaborating in A Competitive World (11th ed.). New York: McGraw-Hill Companies, Inc.

Bechhofer, F., \& McCrone, D. (2009). National Identity, Nationalism and Constitutional Change. In F. Bechhofer \& D. McCrone (Eds.), National Identity, Nationalism and Constitutional Change. Hampshire: Palgrave Macmillan.

Bertens, K. (2013). Etika. Yogyakarta: Penerbit Kanisius.

Bimo, S. (2017). Uji Mediasi dengan Sobel Test. Retrieved February 11, 2019, from http://www.statistikolahdata.com/2017/01/uji-mediasi-dengan-sobel-test.html

Choi, D., Oh, I.-S., \& Colbert, A. E. (2015). Understanding Organizational Commitment : A Meta-Analytic Examination of the Roles of the Five-Factor Model of Personality and Culture. Journal of Applied Psychology, 100(5).

Cohen, A. (2011). Values and Psychological Contracts in Their Relationship to Commitment in the Workplace. Career Development International, 16(7).

Colquitt, J. A., LePine, J. A., \& Wesson, M. J. (2015). Organizational Behavior: Improving Performance and Commitment (4th ed.). New York: McGraw-Hill Education.

Deresky, H. (2014). International Management : Managing Across Borders and Cultures. Essex: Pearson Education Ltd.

Gal, R. (1985). Commitment and Obedience in the Military: An Israeli Case Study. Armed Forces \& Society, 11(4).

George, J. M., \& Jones, G. R. (2012). Understanding and Managing Organizational Behavior (6th ed.). New Jersey: Pearson Education, Inc.

Gibson et al., J. L. (2012). Organizations: Behavior, Structure, Processes (14th ed.). New York: McGraw-Hill Companies, Inc.

Hayes, A. F. (2018). Introduction to Mediation, Moderation, and Conditional Process Analysis. A Regression-based Approach (2nd ed.). New York: The Guildford Press.

Hernandez, P. (2010). Motivation vs Commitment. Retrieved April 27, 2019, from www.thrivepersonalfitness.com/2010/07/motivation-vs-commitment/

Huang, Y. (2015). Impact of Intrinsic Motivation on Organizational Commitment: Empirical Evidences from China. International Business and Management, 2(3). 
Ivancevich, J. M., Konopaske, R., \& Matteson, M. T. (2014). Organizational Behavior and Management (10th ed.). New York: McGraw-Hill Companies, Inc.

Jati, W. R. (2017). Kebangkitan Identitas Lokal di Era Globalisasi Kontemporer: Refleksi NilaiNilai Kebangsaan. In W. R. Jati (Ed.), Relasi Nasionalisme dan Globalisasi Kontemporer. Sebuah Kajian Konseptual. Yogyakarta.

Langton, N., Robbins, S. P., \& Judge, T. A. (2016). Organizational Behaviour: Concepts, Controversies, Applications (7th ed.). Ontario: Pearson Canada Inc.

MacKinnon, D. P. (2008). Introduction to Statistical Mediation Analysis. New York: Lawrence Erlbaum Associates Inc.

McCrone, D., \& Bechhofer, F. (2015). Understanding National Identity. Cambridge: Cambridge University Press.

McShane, S. L., \& Von Glinow, M. A. (2018). Organizational Behavior. Emerging Knowledge. Global Reality (8th ed.). New York: McGraw-Hill Education.

Mercurio, Z. A. (2015). Affective Commitment as a Core Essence of Organizational Commitment: An Integrative Literature Review. Human Resource Development Review, 26(1).

Moore, H. L., \& Moore, T. W. (2014). The Effect of Ethical Climate on the Organizational Commitment of Faculty Members. Journal of Academic and Business Ethics, 9.

Naisbitt, J. (1994). Global Paradox. New York: William Morrow and Company, Inc.

Novianti, L., \& Gunawan, H. (2010). Pengaruh Etika Kerja Islam dan Etika Bisnis terhadap Komitmen Organisasi dengan Komitmen Profesi sebagai Variabel Intervening. Jurnal Manajemen Teori Dan Terapan, 3(2).

Okpara, J. O., \& Wynn, P. (2008). The Impact of Ethical Climate on Job Satisfaction, and Commitment in Nigeria. Implications for Management Development. Journal of Management Development, 27(9).

Preacher, K. J., \& Hayes, A. F. (2004). SPSS and SAS Procedures for Estimating Indirect Effects in Simple Mediation Models. Behavior Research Methods, Instruments, \& Computers, 36(4).

Rahmawati, Y., Abiddin, N. Z., \& Ro'is, I. (2015). Relationship Between Motivation and Organizational Commitment among Scout Volunteers in East Kalimantan. Journal of Social Science Studies, 2(1).

Robbins, S. P., \& Judge, T. A. (2017). Organizational Behavior. Essex: Pearson Education Ltd.

Sairin, S. (2004). The Impact of Globalization on Indonesian Socio-Cultural Life. International Area Review, 7(1).

Soebhan, S. R. (2017). Relasi Nasionalisme Kebangsaan, Globalisasi, dan Kedaulatan Negara. In W. R. Jati (Ed.), Relasi Nasionalisme dan Globalisasi Kontemporer. Sebuah Kajian Konseptual. Jakarta: Pustaka Pelajar.

Supriyatno, M. (2014). Tentang Ilmu Pertahanan. Jakarta: Yayasan Pustaka Obor Indonesia.

Suriasumantri, J. S. (2017). Filsafat Ilmu. Sebuah Pengantar Populer Keterkaitan Ilmu, Agama dan Seni. Jakarta: Pustaka Sinar Harapan.

Syed, N., Saeed, A., \& Farrukh, M. (2015). Organizational Commitment and Five Factor Model Personality: Theory Recapitulation. Journal of Asian Business Strategy, 5(8).

Vitell, S. J., \& Singhapakdi, A. (2008). The Role of Ethics Institutionalization in Influencing 
Organizational Commitment, Job Satisfaction, and Esprit de Corps. Journal of Business Ethics, 81 .

Williamson, I. O., Burnett, M. F., \& Bartol, K. M. (2009). The Interactive Effect of Collectivism and Organizational Rewards on Affective Organizational Commitment. Cross Cultural Management: An International Journal, 16(1). 
